\title{
Efektivitas Pengembangan E-Book Fisika Berbasis Discovery Learning Tema Gempa Bumi untuk Meningkatkan Kompetensi Sikap Tangguh Peserta Didik
}

\author{
Fitrah Ayu' ${ }^{1)}$, Ahmad Fauzi ${ }^{2)}$ \\ ${ }^{1)}$ Program Studi Magister Pendidikan Fisika Pascasarjana Universitas Negeri Padang \\ ${ }^{2}$ Dosen Program Studi Magister Pendidikan Fisika Pascasarjana Universitas Negeri Padang \\ fitrahayu97@yahoo.com
}

\begin{abstract}
The problem in this research is that the attainment of competence attitudes of students is still not optimal, namely the tough attitude of students in facing earthquake disasters. This development research aims to determine the level of effectiveness of using the integrated Physics e-book material for earthquake disaster mitigation in physics learning to improve the competence of students' resilient attitude. This type of research is Research and Development $(R \& D)$. The development model used is the Plomp development model which consists of three stages, namely the preliminary research phase, the development or prototyping phase, and the assessment phase. This study only describes the results of the assessment phase, namely the competence of students' attitudes. The method used in this research is descriptive method with data collection instruments, namely self-assessment in the form of questionnaires filled out by students. This research was conducted at 14 Padang Senior High School for the 2019/2020 Academic Year on wave material. The results of this study indicate that the integrated physics e-book earthquake mitigation material is effectively used in the learning process with the average percentage of students' attitudes for three meetings, namely $81 \%$ in the very effective category.
\end{abstract}

Keywords : E-book, Earthquake, Mitigastion, Effective

This is an open access article distributed under the Creative Commons 4.0 Attribution License, which permits unrestricted use, distribution, and reproduction in any medium, provided the original work is properly cited. $@ 2018$ by author and Universitas Negeri Padang.

\section{PENDAHULUAN}

Salah satu tujuan dari pendidikan nasional yang tertuang dalam Pasal 3 UU Republik Indonesia No. 20 Tahun 2003 mengenai Sistem Pendidikan Nasional menyatakan bahwa pendidikan berfungsi membentuk watak, mengembangkan potensi serta mencerdasakan kehidupan negara yang bermartabat, bertujuan untuk meningkatkan potensi daripada peserta didik agar menjadi manusia yang bertakwa dan beriman kepada Tuhan Yang Maha Esa, kreatif, berakhlak mulia, mandiri, sehat, cakap, berilmu, serta menjadi warga negara yang bertanggungjawab dan demokratis (UU No. 20 Tahun 2003). Pendidikan yang bermutu akan menghasilkan SDM yang berkualitas dan mampu berkompetensi di negara-negara lain. Berbagai cara telah dilaksanakan oleh pemerintah untuk meningkatkan mutu pendidikan. Diantaranya adalah dengan merevisi kurikulum sebelumnya yang diharapkan dapat menjadi lebih berkualitas lagi sehingga tujuan pendidikan nasional yang diharapkan dapat tercapai. Penyempurnaan itu salah satunya dimulai dari Kurikulum Berbasis Kompetensi dan sekarang ini sudah berlaku Kurikulum 2013.
Kurikulum secara bahasa berasal dari kata Curere bahasa Yunani yang diartikan sebagai jarak yang dilalui atau ditempuh oleh peserta didik mulai dari pembukaan pembelajaran sampai penutupan pembelajaran. Kurikulum diartikan sebagai rencana pendidikan yang mempunyai kedudukan penting dalam seluruh aspek pendidikan. Istilah kurikulum sering dimaknai sebagai plan for learning atau rencana pelaksanaan pendidikan, sebagai rencana pelaksanaan pendidikan kurikulum memberikan pedoman serta pegangan tentang lingkup, jenis, isi, urutan, dan proses daripada pelaksanaan pendidikan (Aziz, 2018). Disisi lain, Peraturan Pemerintah Nomor 32 Tahun 2013 Pasal 77B Ayat 9 menjelaskan bahwa struktur kurikulum untuk satuan pendidikan menengah salah satunya adalah muatan umum yang merupakan keunikan daerah. Sehingga materi mitigasi bencana gempa bumi dapat dilaksanakan di sekolah. Adapun karakteristik yang membeda kan penerapan kurikulum 2013 dengan kurikulum yang sebelumnya adalah pendekatan pembelajaran yang terapkan. Kurikulum 2013 pendekatan yang diterapkam adalah pendekatan saintifik atau scientific approach. Pendekatan 
saintifik ini bertujuan dalam memberikan pemahaman kepada peserta didik dalam memahami, mengenal berbagai materi pembelajaran menggunakan pendekatan ilmiah, bahwa informasi bisa didapatkan kapan saja, dan dimana saja, serta tidak bergantung pada informasi yang diberikan oleh guru secara searah (Majid, 2013). Penerapan pendekatan saintifik menjadi tantangan bagi guru melalui pengembangan aktivitas peserta didik dalam pembelajaran Fisika.

Belajar diartikan sebagai suatu kegiatan yang memperlihatkan adanya perubahan pada diri seseorang. Perubahan sebagai dampak dari proses belajar dapat diamati dalam berbagai bentuk seperti perubahan tingkah laku, keterampilan, sikap, kecakapan, pengetahuan, dan perubahan-perubahan lainnya yang ada pada diri seseorang yang telah belajar (Santoso, 2017). Belajar juga diartikan sebagai perubahan dalam diri yang dimanifestasikan sebagai suatu respon yang berpola yang berupa kebiasaan, pemahaman, keterampilan, bahkan sikap (Darmwan, 2012). Belajar merupakan kegiatan internal yang sangat kompleks, proses internal yang terlibat tersebut adalah mental yang meliputi aspek pengetahuan, sikap, dan keterampilan (Nildawati, 2013). Proses belajar pada peserta didik hendaknya berlangsung terarah, untuk itu guru harus mampu menciptakan suasana belajar yang kondusif dalam pembelajarn.

Pembelajaran merupakan proses yang melibatkan guru dan siswa sebagai pendidik dan peserta didik. Proses interaksi yang terjadi antara peserta didik dengan pendidik maupun peserta didik dan peserta didik. Proses pembelajaran diharapkan mampu untuk mencapai tujuan pendidikan nasional. Pembe lajaran dibutuhkan untuk meningkatkan kemampuan yang dimiliki oleh peserta didik. Kegiatan embelajaran merupakan sesuatu yang kompleks, dikarenakan dalam pembelajaran selalu mengintegrasikan berbagai kegiatan dan komponen, yaitu lingkungan belajar peserta didik dengan pendidik untuk diperoleh perubahan hasil belajar dan sikap sesuai dengan kompetensi serta tujuan yang ditetapkan (Rusman, 2012). Pembelajaran Fisika yang baik memiliki unsur penting yang membangun pembelajaran tersebut. Unsur penting dalam pembelajaran yang baik adalah (a) peserta didik yang belajar, (b) guru yang mengajar, (c) bahan pelajaran, (d) hubungan antara guru dan peserta didik (Suparno, 2007).

Kompetensi daripada peserta didik adalah kemampuan penguasaan yang dimiliki peserta didik yang meliputi keterampilan, sikap, dan pengetahuan yang diperoleh dari pembalajaran. Setiap peserta didik memiliki kompetensi dalam dirinya, namun harus dikembangkan agar memperoleh hasil yang maksimal. Berdasarkan Peraturan Pemerintah Nomor 32 Tahun 2013 kompetensi adalah seperangkat keterampilan, pengetahuan, dan sikap yang harus dihayati, dimiliki, serta dikuasai oleh peserta didik setelah belajar suatu pembelajaran, menyelesaikan satuan pendidikan tertentu. Atau menamatkan suatu program tertentu. Kompetensi merupakan sesuatu yang dimiliki oleh peserta didik, yang merupakan komponen penting yang harus dirumuskan dalam kegiatan pembelajaran, yang memiliki peranan yang sangat penting dalam menentukan arah pembelajaran (Mulayasa, 2014). Permendikbud Nomor 54 tentang standar kompetensi lulusan Tahun 2013 menyatakan bahwa standar kompetensi daripada lulusan adalah suatu kriteria mengenai kualifikasi kemampuan lulusan yang meliputi aspek sikap, pengetahuann, dan keterampilan. Berdasarkan Permendikbud Nomor 104 Tahun 2014 bahwa sikap bermula dari perasaan (suka atau tidak suka) yang terkait dengan kecenderungan seseorang dalam merespon sesuatu atau objek. Sikap sebagai ekspresi dari nilai-nilai atau pandangan hidup yang dimiliki oleh seseorang, serta dapat dibentuk hingga tejadi perubahan perilaku atau tindakan yang diharapkan, Tindakan yang diharapkan adalah peserta didik memiliki percaya diri, jujur, objektif, membentuk sikap terhadap mata pelajaran Fisika, dan membentuk sikap tangguh dalam menghadapi bencana gempa bumi.

Disisi lain Indonesia merupakan wilayah yang memiliki tingkat keaktifan gempa yang sangat tinggi. Dikarenakan Indonesia berada di kawasan jalur teraktif gempa bumi di dunia karena berada di atas tiga lempeng yang bertumbukan yakni, Pasifik dari Timur, Eurasia dari utara, serta Indo-Australia dari sebelah selatan. Rata-rata telah terjadi 6.512 gempa bumi setiap tahunnya di Indonesia (Sabtaji, 2020). Sumatera Barat adalah salah satu kawasan di Indonesia yang sering dilanda gempa bumi sehingga memiliki damapak bagi keberlangsungan masyarakatnya. Masyarakat 
yang tidak tahu bagaimana cara menghadapi peristiwa gempa bumi akan memperburuk keadaan, karena gempa bumi merupakan bencana alam yang terjadi namun tidak terprediksi.

Salah satu cara untuk mengurangi dampak yang ditimbulkan dari bencana gempa bumi dibutuhkan mitigasi bencana gempa bumi. Mitigasi bencana bertujuan untuk mengurangi dampak negatif bencana bagi keberlangsungan hidup masyarakat yang berada di kawasan rawan bencana (UU No. 24 Tahun 2004). Kegiatan mitigasi ini dapat dilaksanakan diinstansi pendidikan formal yaitu sekolah. Mitigasi bencana gempa bumi dapat diintegrasikan melalui pembelajaran Fisika. Fisika merupakan bagian dari ilmu pengetahuan alam yang mempelajari gejala atau fenomena yang ada di alam (Halim, 2012). Fisika diperoleh melalui metode imliah untuk mengkaji gejala-gejala fisis alam (Festiyed, 2013). Pengintegrasian materi mitigasi bencana gempa bumi dapat dimuat dalam sebuah bahan ajar.

Bahan ajar adalah bagian dari sumber belajar. Bahan ajar merupakan segala bentuk bahan pembelajaran yang digunakan oleh guru dan membantu guru dalam melaksanakan proses pembelajaran (Depdiknas, 2008). Bahan ajar merupakan segala bentuk dari sumber belajar yang digunakan oleh pendidik dalam menyampaikan materi pembelajaran (Asrizal, 2017). Bahan ajar iala segala sesuatu yang digunakan untuk mendukung, memfasilitasi, mempengaruhi, atau mendorong tercapainya kompetensi peserta didik (Asrizal, 2018). Hal ini sejalan dengan pendapat Majid (2012) yang mengatakan bahwa bahan ajar adalah segala bentuk bahan yang digunakan untuk membantu pendidik dalam melaksanakan kegiatan pembelajarn di sekolah. Selain itu, bahan ajar digunakan dalam proses pembelajaran berfungsi membantu peserta didik dalam memahami materi pembelajaran. Dengan menggunakan bahan ajar memungkinkan peserta didik untuk memahami kompetensi yang akan dicapai secara berurutan sehingga peserta didik menguasai semua kemapuan secara keseluruhan dan diperoleh pembelajaran yang berkualitas dan bermakna. Salah satu contoh bahan ajar adalah buku.

Buku diartikan sebagai bahan tertulis yang berisikan ilmu pengetahuan hasil pikir dari penulisnya (Depdiknas, 2008). Menurut kamus oxford buku diartikan sebagai book is number of sheets of pape, either printed of blank, fastened together in a cover. Buku merupakan sejunlah lembar-lembaran kertas baik kosong ataupun cetakan yang dijilid serta diberi cover. Buku dikatakan sebagai bahan ajar adalahbuku yang berisi suatu ilmu dan pengetahuan hasil dari analisis terhadap bentuk yang tertulis. Buku yang sesuai dengan perkembangan zaman adalah $e$-book.

Electronic book atau yang dikenal dengan sebutan e-book merupakan buku dalam format tulisan yang dikonversikan ke format digital, $e$ book juga mempunyai pengertian sebagai kawasan belajar yang mengandung database yang menyimpan materi dalam sebuah pembelajaran (Restiyowati, 2012). Buku pada umumnya terdiri atas kumpulan kertas yang berisi tulisan dan gambar, e-book berisikan informasi dalam bentuk digital dan dapat juga berwujud teks dan gambar (Prabowo, 2013). Ebook berisikan informasi digital yang dapat berisi tulisan-tulisan, gambar-gambar, audio, video. E-book merupakan sebuah publikasi yang terdiri dari teks, gambar, maupun suara, dan dipublikasikan dalam bentuk digital yang dapat dibaca di komputer maupun alat elektronik lainnya (Isnantyo, 2019).

Secara umum, e-book harus memuat bagian awal, isi dan penutup. Bagian awal $e$ book terdiri dari halaman judul, halaman penerbit, halaman kata pengantar, halaman daftar isi, halaman daftar gambar, halaman daftar tabel, dan penomoran halaman. Bagian isi e-book terdiri dari kompetensi inti, kompetensi dasar, indikator pencapaian kompetensi, materi, video, latihan soal, dan uji kompetensi. Bagian akhir terdiri dari glosarium, daftar pustaka, indeks, dan lmapiran (Permendikbud, 2016).

Peran penting $e$-book dalam kegiatan atau proses pembelajaran didasari oleh cirri-ciri $e$ book yang lebih kompleks dibandingkan buku cetak. Beberapa karakteristik e-book antara lain : 1) memanfaatkan keunggulan komputer, 2) memanfaatkan teknologi, sehingga suasana pembelajaran menjadi tidak bosan, serta menarik dan pada akhirnya memberikan memotivasi peserta didik untuk belajar secara mandiri, 3) menggunakan e-book bersifat mandiri, dapat disimpan di komputer sehingga dapat dihunakan oleh pendidikan dan peserta didik dimana saja dan kapan saja bila yang bersangkutan membutuhkan, dan 4) memanfaatkan pertukaran data yang dapat 
dilihat setiap waktu di komputer (Depdiknas, 2008).

Kelebihan daripada e-book antara lain adalah : 1) ukuran fisik $e$-book kecil, karena $e$ book tersimpan dalam format digital, dapat disimpan di dalam penyimpanan data (hardisk, flash disk) dalam bentuk word, pdf, maupun swf, 2) mudah dibawa, e-book dapat dibawa dengan mudah melalui flashdisk, serta media penyimpanan yang lainnya, 3) tidak mudah rusak, e-book tidak akan rusak seperti layaknya buku pada umumnya, format digital e-book dapat bertahan sepanjang waktu dengan kualitas yang akan tidak berubah, 4) mudah diproses, isi dari e-book dapat dijelajahi maupun dilacak dengan cepat dan mudah, format e-book yang ada saat ini sangat memungkinkan akan hal tersebut, 5) mudah digandakan, pelipatgandaan atau copying e-book sangat murah dan mudah, untuk membuat ratusan copy dari e-book dapat dilakukan dengan cepat dan sangat mudah, sementara untuk mencetak ratusan buku membutuhkan waktu yang sangat lama dan biaya yang sangat mahal, 6) mudah dalam pendistribusian, pendistribusian dapat mengguna kan media seperti internet, pengiriman e-book dari Amerika ke Indonesia atau ke Inggris dapat dilakukan dalam periode menit, dan 7) ragam reader, banyak sekali ragam e-book reader yang tersedia di pasaran, baik melalui PC, gadget $e$ reader, dan lainnya (Fani, 2016).

E-book Fisika dapat digunakan dalam proses pembelajaran. Proses pembelajaran Fisika pada Kurikulum 2013 menggunakan model pembelajaran, Model pembelajaran diartikan sebagai suatu pola atau maupun rencana yang dapat digunakan untuk membentuk rancangan pembelajaran jangka panjang, mebuat bahan-bahan pembelajaran, dan kegiatan bimbingan pembelajaran selama proses pembelajaran (Joyce, 1980). Model pembe lajaran dapat dijadikan sebagai pola pilihan, sehingga guru boleh memilih model pembelajaran yang sesuai dengan karakteristi peserta didik dan efisien dalam mencapai tujuan pembelajaran (Rusman, 2010). Salah satu model pembelajaran yang sesuai untuk mata pelajaran Fisika adalah model pembelajaran penemuan atau dikenal dengan sebutan discovery learning.

Discovery learning merupakan salah satu model pembelajaran yang berpusat kepada peserta didik belajar aktif, yang bertujuan memberikan kesempatan kepada peserta didik menjadi seprang problem solver (Qadriyah, 2015). Menurut Kusuma (2015) model pembelajaran discovery learning merupakan suatu model untuk mengembangkan kemampuan belajar peserta didik yang aktif dengan menyelidiki sendiri, menemukan sendiri, maka hasil yang akan diperoleh akan tahan lama dalam ingatan. Model pembelajaran discovery learning merupakan model pembalajaran yang mendorong peserta didik untuk selalu aktif menemukan pengetahuan yang belum disampaikan oleh guru (Wahjudi, 2015).

Model pembelajaran berbasis penemuan atau discovery learning memiliki beberapa kelebihan yaitu : 1) membantu peserta didik meningkatkan keterampilan, dan memperbaiki proses berpikir, 2) model ini memungkinkan peserta didik untuk berkembang dengan cepat dan sesuai dengan perkembangan dan kecepatan sendiri, 3) meningkatkan tigkat pemberiaan penghargaan kepada peserta didik, karena adanya diskusi, 4) menimbulkan rasa senang pada peserta didik, karena tumbuhnya rasa menyelidika dan berhasil, dan 5) membantu peserta didik menemukan pemahaman secara final dan pasti tanpa adanya keragu-raguan (Muhammad, 2016).

Efektivitas berasal dari kata effective yakni bahasa inggris yang artinya tepat, berhasil, atau manjur. Efektivitas menunjukkan suatu tingkatan keberhasilan pencapaian suatu tujuan. KBBI mendefiniskan efektif dengan adanya pengaruh atau dapat membawa keberhasilan, sehingga efektivitas diartikan sebagai keadaan yang berpengaruh, hal berkesan atau keberhasilan dalam mencapai tujuan pembelajaran. Dalam penelitian dan pengem bangan dibidang pendidikan, aspek untuk menyatakan bahwa keterlaksanan produk dikatakan efektif dapat dilihat dari aspek hasil belajar peserta didik, kegiatan peserta didik, dan kemampuan Fisika peserta didik (Rochmad, 2012). Jadi efektivitas dapat disimpulkan sebagai suatu proses daripada pencapaian suatu tujuan yang telah ditetapkan sebelumnya. Artinya e-book Fisika dikatakan efektif apabila digunakan dalam pembelajaran dapat meningkat kan hasil belajar peserta didik. Efektivitas dilihat dari kompetensi sikap. Rumusan masalah dalam penelitian ini ialah bagaimana tingkat keefektifan e-book Fisika tema gempa bumi dalam proses pembelajaran untuk meningkatkan kompetensi sikap tangguh peserta didik? 
Berdasarkan rumusan masalah, maka adapun tujuan penelitian ini ialah untuk mengetahui tingkat keefektifan e-book Fisika tema gempa bumi untuk meningkatkan kompetensi sikap tangguh peserta didik.

\section{METODE PENELITIAN}

Jenis penelitian yang sesuai berdasarkan permasalahan dan tujuan yang telah dirumuskan adalah penelitian dan pengembangan atau Research and Development $(R \& D)$. Metode penelitian dan pengembangan dalam bahasa inggris yakni research and development merupakan metode penelitian yang digunakan untuk menghasilkan produk tertentu, dan menguji produk tersebut (Sugiyono, 2012). Dalam penelitian ini produk yang dihasilkan dan dilakukan pengujian adalah e-book Fisika terintegrasi materi mitigasi bencana gempa bumi.

Prosedur pengembangan e-book Fisika dilakukan sesuai dengan fase model pengembanganPlomp menggunakan tiga tahap yakni preliminary research phase, development or prototyping phase, dan, assesment phase. Penelitian ini hanya memaparkan hasil pada tahap assessment phase yakni kompetensi sikap peserta didik.

Instrumen yang digunakan untuk mengumpulkan data yakni penilaian diri oleh peserta didik berupa angket. Instrumen penilaian diri digunakan untuk mengetahui keefektifan dari e-book yang dihasilkan. Analisis e-book Fisika gempa bumi berupa : 1) rasa percaya diri, 2) jujur, 3) membentuk sikap terhadap mata pelajaran Fisika, dan 4) membentuk sikap tangguh dalam menghadapi bencana gempa bumi. Nilai efektivitas e-book untuk sikap ditentukan dengan menggunakan rumus :

Nilai $=\frac{\text { Skor yang diperoleh }}{\text { Skor maksimum }} \times 100 \%$

Berdasarkan nilai efektivitas, maka dapat ditentukan kriteria efektivitas sebagai berikut: Tabel 1. Kategori Penilaian Sikap

\begin{tabular}{|c|c|c|}
\hline No & $\begin{array}{c}\text { Persentase } \\
\text { Ketercapaian } \\
\text { Indikator }\end{array}$ & Kategori \\
\hline 1 & $0-20$ & Tidak Efektif \\
\hline 2 & $21-40$ & Kurang Efektif \\
\hline 3 & $41-60$ & Cukup Efektif \\
\hline 4 & $61-80$ & Efektif \\
\hline 5 & $81-100$ & Sangat Efektif \\
\hline
\end{tabular}

Sumber : (Wahyuni, 2018).

\section{HASIL DAN PEMBAHASAN}

Data yang diperoleh dalam penelitian ini adalah data kompetensi sikap peserta didik SMAN 14 Padang dengan menggunakan lembar penilaian diri yang terdiri atas lima aspek yakni : 1) rasa percaya diri, 2) jujur, 3) membentuk sikap terhadap mata pelajaran Fisika, dan 4) membentuk sikap tangguh dalam menghadapi bencana gempa bumi. E-book Fisikayang diujicobakan di SMAN 14 Padang ini sudah berada pada kategori valid dan sangat praktis. Hasil analisis kompetensi sikap untuk aspek rasa percaya diri dapat dilihat pada Gambar 1 .

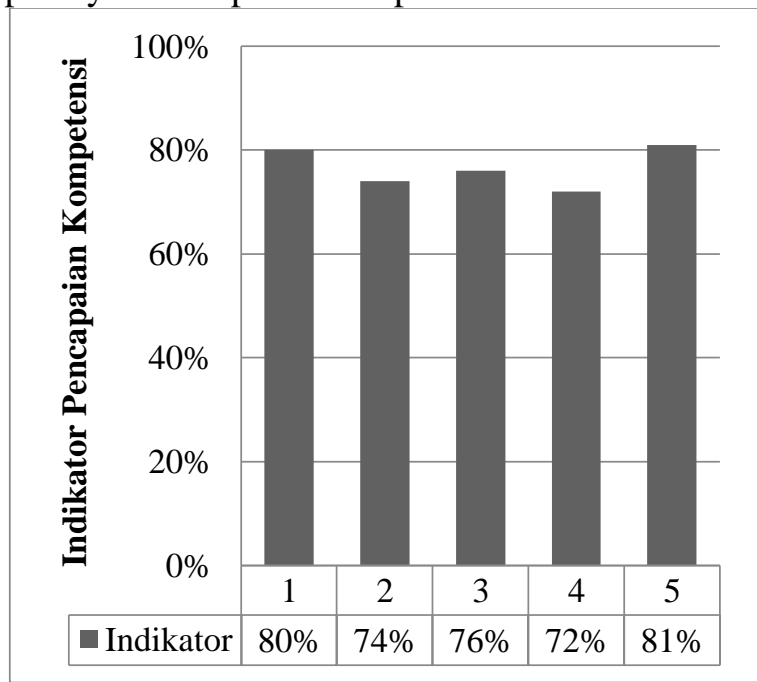

Gambar 1. Aspek Rasa Percaya Diri

Gambar 1 merupakan hasil analisis uji efektivitas untuk kompetensi sikap pada aspek rasa percaya diri yang terdiri atas lima indikator. Indikator pertama yakni peserta didik tidak menyerah dalam mempelajari Fisika dengan persentase pencapaian indikator $80 \%$ berada pada kategori efektif. Indikator kedua yakni peserta didik berusaha mengerjakan tugas-tugas Fisika sendiri dengan pencapaian indikator $74 \%$ berada pada kategori efektif. Indikator ketiga yakni peserta didik mengkomunikasikan kembali konsep-konsep Fisika yang dipahami dengan pencapaian indikator $76 \%$ berada pada kategori efektif.

Indikator keempat yakni peserta didik berani menyampaikan pendapat di kelas dengan pencapaian indikator $72 \%$ berada pada kategori efektif. Indikator kelima yakni peserta didik penuh rasa tanggungjawab menyelesaikan tugastugas Fisika dengan pencapaian indikator $81 \%$ berada pada kategori sangat efektif, Persentase 
rata-rata pencapaian indikator untuk aspek rasa percaya diri yakni $77 \%$ berada pada kategori efektif. Hasil analisis kompetensi sikap untuk aspek jujur dapat dilihat pada Gambar 2.

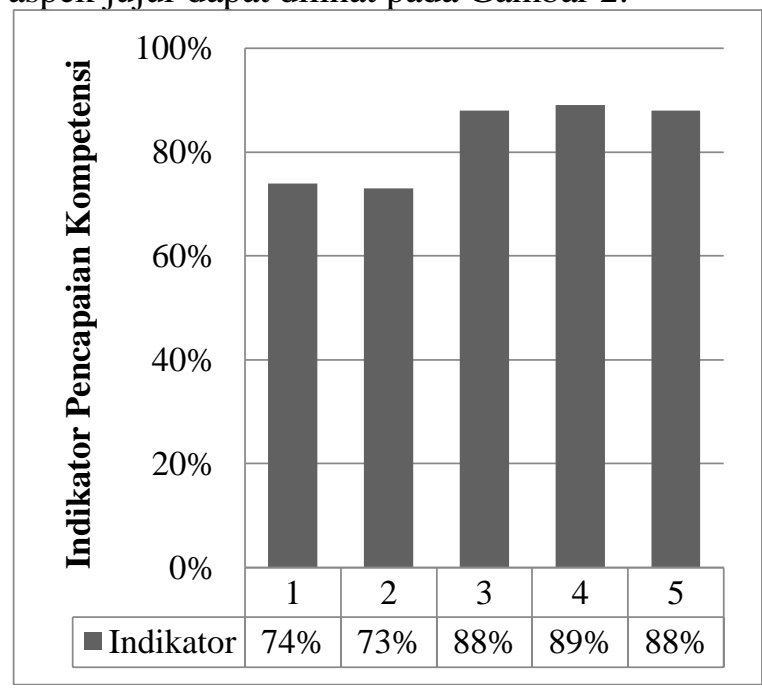

Gambar 2. Aspek Jujur

Gambar 2 merupakan hasil analisis uji efektivitas untuk kompetensi sikap pada aspek jujur yang terdiri atas lima indikator. Indikator pertama yakni peserta didik tidak menyontek pad saat mengerjakan ulangan dengan persentase pencapaian indikator $74 \%$ berada pada kategori efektif. Indikator kedua yakni peserta didik mengerjakan soal ujian tanpa melihat jawaban teman dengan persentase ketercapaian indikator $73 \%$ berada pada kategori efektif. Indikator ketiga yakni peserta didik berani mengakui kesalahan yang dilakukan dengan persentase ketercapaian indikator $88 \%$ berada pada kategori sangat efektif.

Indikator keempat yakni peserta didik menerima masukan tentang kekurangannya dari teman-teman dengan persentase pencapaian indikator $89 \%$ berada pada kategori sangat efektif. Indikator kelima yakni peserta didik menerima teguran dari teman-temannya jika melakukan kesalahan dengan persentase ketercapaian indikator $88 \%$ berada pada kategori sangat efektif. Persentase rata-rata pencapaian indikator untuk aspek jujur yakni $82 \%$ berada pada kategori sangat efektif. Hasil analisis kompetensi sikap untuk aspek membentuk sikap terhadap mata pelajaran Fisika dapat dilihat pada Gambar 3.

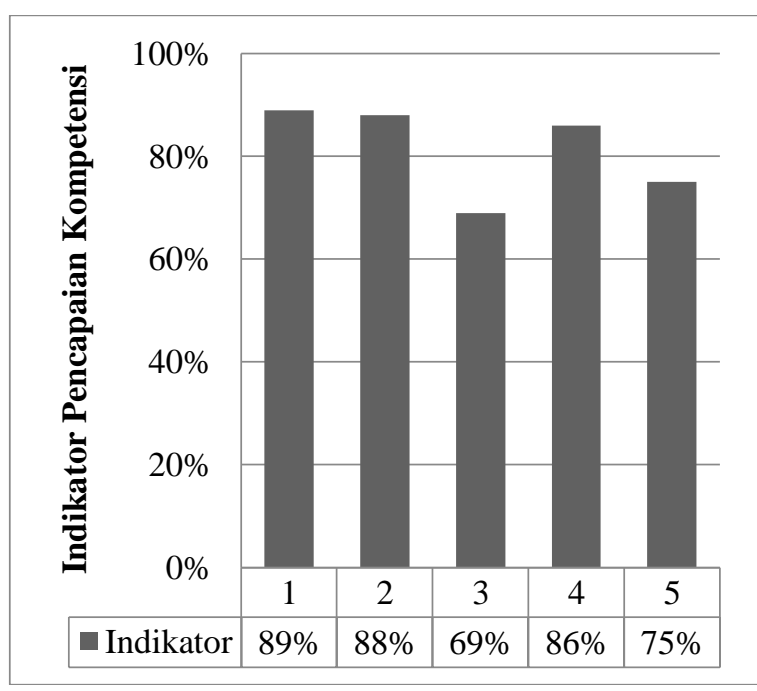

Gambar 3. Membentuk Sikap Terhadap Mata Pelajaran Fisika

Gambar 3 merupakan hasil analisis uji efektivitas untuk kompetensi sikap pada aspek membentuk sikap terhadap mata pelajaran Fisika yang terdiri atas lima indikator. Indikator pertama yakni peserta didik semakin yakin dengan kebesaran Tuhan Yang Maha Esa setelah mempelajari Fisika dengan persentase pencapaian indikator $89 \%$ berada pada kategori sangat efektif. Indikator kedua yakni peserta didik bersyukur dengan karunia Tuhan Yang Maha Esa melalui pembelajaran Fisika dengan persentase pencapaian indikator $88 \%$ berada pada kategori sangat efektif. Indikator yang ketiga yakni Fisika merupakan mata pelajaran yang disukai oleh peserta didik dengan persentase ketercapaian indikator $69 \%$ berada pada kategori efektif.

Indikator keempat yakni peserta didik selalu menghargai pendapat teman ketika diskusi dengan persentas ketercpaian indikator $86 \%$ berada pada kategori sangat efektif. Indikator kelima yakni peserta didik berusaha menolong teman yang kesulitan dalam pembelajaran Fisika dengan persentase ketercapaian indikator $75 \%$ berada pada kategori efektif. Persentase rata-rata pencapaian indikator untuk aspek membentuk sikap terhadap mata pelajaran Fisika yakni $81 \%$ berada pada kategori sangat efektif. . Hasil analisis kompetensi sikap untuk aspek membentuk sikap tangguh dalam menghadapi bencana gempa bumi dapat dilihat pada Gambar 4. 


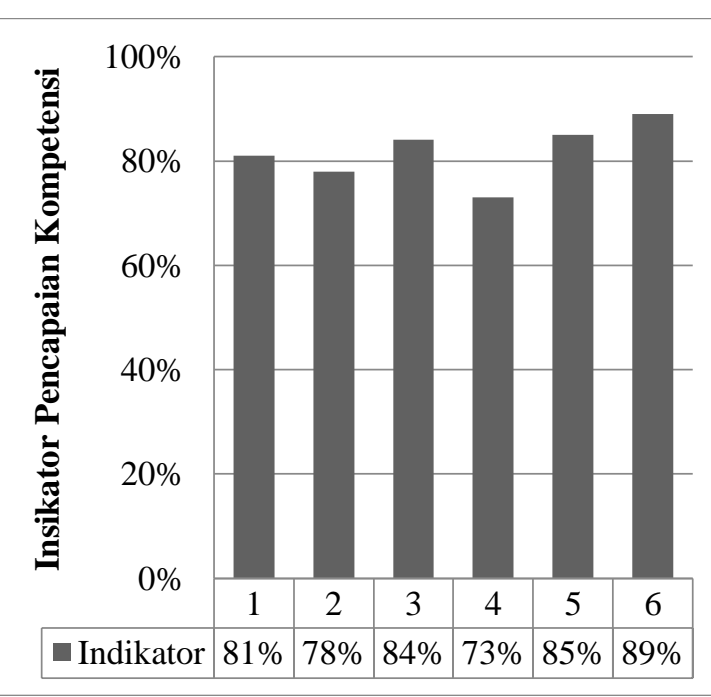

Gambar 4. Mmembentuk Sikap Tangguh dalam Mengahadapi Bencana Gempa Bumi

Gambar 4 merupakan hasil analisis uji efektivitas untuk kompetensi sikap pada aspek membentuk sikap tangguh dalam menghadapi bencana gempa bumi yang terdiri atas enam indikator. Indikator pertama yakni peserta didik ikut memberikan penjelasan pada orang sekitar bagaimana sikap kita saat terjadi gempa bumi dengan persentase ketercapaian indikator $81 \%$ berada pada kategori sangat efektif. Indikator kedua yakni peserta didik tidak panic ketika mendengar berita yang menyatakan akan terjadi gemba bumi dengan kekuatan besar dengan persentase ketercapaian indikator $78 \%$ berada pada kategori efektif. Indikator ketiga yakni peserta didik tidak menangis saat terjadi gempa bumi dengan persentase ketercapaian indikator $84 \%$ berada pada kategori sangat efektif. Indikator keempat yakni saat terjadi gempa bumi peserta didik hanya fokus pada keselamatan pribadi dengan persentase ketercapaian indikator $73 \%$ berada pada kategori efektif.

Indikator kelima yakni peserta didik berkumpul di satu titik yang sudah ditentukan untuk penyelamat diri dengan persentase ketercapaian indikator $85 \%$ berada pada kategori sangat efektif. Indikator keenam yakni peserta didik mewaspadai bencana gempa bumi susulan yang terjadi dengan persentase ketercapaian indikator $89 \%$ berada pada kategori sangat efektif. Persentase rata-rata pencapaian indikator untuk aspek membentuk sikap tangguh dalam menghadapi bencana gempa bumi yakni $82 \%$ berada pada kategori sangat efektif. Secara umum hasil kompetensi sikap peserta didik setiap pertemuan dapat dilihat pada Gambar 5.

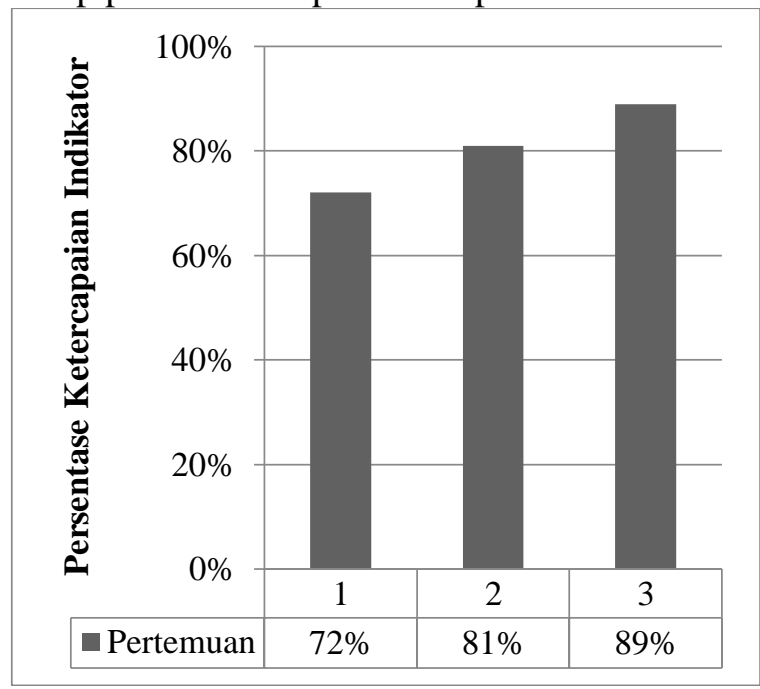

Gambar 5. Kompetensi Sikap Setiap Pertemuan

Gambar 5 merupakan hasil analisis kompetensi sikap peserta didik untuk setiap pertemuan. Persentase rata-rata kompetensi sikap peserta didik untuk tiga kali pertemuan yakni $81 \%$ berada pada kategori sangat efektif. Hal ini menunjukkan bahwa e-book Fisika terintegrasi materi mitigasi bencana gempa bumi sangat efektif meningkatkan kompetensi sikap peserta didik dalam proses pembelajaran. Setiap pertemuan terlihat hasil penilaian diri peserta didik mengalami peningkatan. Hasil ini relevan dengan penelitian Hartini (2018) yang menyatakan peningkatan sikap perlu dibiasan secara terus menerus dalam proses pembelajaran, salah satu cara untuk meningkatkan kompetensi sikap peserta didik yaitu dengan menggunakan bahan ajar. Sehingga e-book Fisika tema gempa bumi dikatakan efektif untuk meningkatkan kompetensi sikap tangguh peserta didik.

\section{KESIMPULAN}

Berdasarkan hasil penelitian serta pembahasan dalam penelitian ini dapat disimpulkan bahwa e-book Fisika tema gempa bumi efektif untuk meningkatkan kompetensi sikap tangguh peserta didik.

\section{DAFTAR PUSTAKA}

Asrizal,. Festiyed., \& Ramadhan, S. (2017). Analisis Kebutuhan Pengembangan Bahan Ajar IPA Terpadu Bermuatan Literasi Era 
Digital untuk Pembelajaran Fisika SMP Kelas VIII. Jurnal Eksakta Pendidikan (JEP), 1(1), 1-8.

Asrizal., Ali, A., Ananda., Festiyed., Suci, K. (2018). Effectiveness of Integrated Science Instructional Material on Pressure in Daily Life theme to Improve Digital Age Literacy of Students. International Conference on Science Education. 1006012031 : 1-9.

Aziz, R. (2018). Implementasi Pengembangan Kurikulum. Jurnal UIN Alauddin Makasar, $\&(1), 44-50$.

Darmawan, D. (2012). Kurikulum Pembelajaran. Bandung : Reamaja Rosda Karya.

Departemen Pendidikan Nasional. (2008). Panduan Pengembangan Bahan Ajar. Jakarta : Direktorat Pembinaan Sekolah Menengah Atas.

Fani, I. T. (2016). Pengembangan E-Book Interaktif Elektrokimia Berbasis Kehidupan Sehari-Hari. Bandar Lampung: Universitas Lampung.

Festiyed,. \& Yulkifli. (2013). Internalisasi Integrasi Karakteristik Religius pada Materi Fisika. Seminar Nasional Pembalajaran Fisika, 1-8.

Halim, A. (2012). Pengaruh Strategi Pembelajaran dan Gaya Belajar Terhadap Hasil Belajar Fisika Siswa SMPN 2 Secanggang Kabupaten Langkat. Jurnal Tabularasa PPS UNIMED, 3(2), 141- 158.

Hartini, S. (2018). Developing of Physics Learning Materials Based on Scientific Literacy to Train Scientific Process Skilss. Journal of Physics, 1097012302 : 1-7.

Isnantyo, F. D., Sumarni, S., \& Siswanto, B. (2019). Pendampingan Pengembangan Bahan Ajar Melalui Digital Book pada Guru-Guru SMK Teknik Bangunan. Senadimas UNISRI, 90-96.

Joyce, B., \& Weil. (1980). Model of Teaching. London : Allyn and Bacon.

Kusuma, T. A., Indrawati, \& Harijanto, A. (2015). Model Discovery Learning Disertai Teknik Probing Prompting dalam Pembelajaran Fisika di MA. Jurnal Pendidikan Fisika, 3(4), 336-341. Majid, A. (2012). Perencanaan Pembelajaran Mengembangkan Standar Kompetensi Guru. Bandung : Remaja Rosda Karya

Volume 5| Nomor 1|Mei 2021|Page 8-16
Majid, A. (2013). Implementasi Kurikulum 2013. Bandung : Interest Media.

Muhammad, N. (2016). Pengaruh Metode Discovery Learning untuk Meningkatkan Representasi Matematis dan Percaya Diri Siswa. Jurnal Pendidikan Universitas Garut, 9(1) : 922.

Mulyasa, E. (2014). Pengembangan Implementasi Kurikulum 2013. Bandung : Remaja Rosdakarya.

Nildawati. (2013). Belajar dala Perspektig Psikologi Islam. Jurnal Pioner, 1(1), 1-13.

Peraturan Menteri Pendidikan dan Kebudayaan Republik Indonesia Nomor 54 Tahun 2013 tentang Standar Kompetensi Luluesan Pendidikan Dasar dan Menengah.

Peraturan Menteri Pendidikan dan Kebudayaan Republik Indonesia Nomor 104 Tahun 2014 tentang Penilaian Hasil Belajar oleh Pendidikan pada Pendidikan Dasar dan Pendidian Menengah.

Peraturan Menteri Pendidikan dan Kebudayaan Republik Indonesia Nomor 8 Tahun 2016 tentang Buku yang Digunakan oleh Satuan Pendidikan.

Peraturan Pemerintah Nomor 32 Tahun 2013 tentang Perubahan Atas Aturan Pemerintah Nomor 19 Tahun 2005 tentang Standar Pendidikan Nasional.

Prabowo, A., \& Heriyanto. (2013). Analisis Pemanfaatan Buku Elektronik (E-Book) oleh Pemustaka di Perpustakaan SMA Negeri 1 Semarang. Jurnal Perpustakaan, 2(2), 1-9

Restiyowati, I., \& Sanjaya, I, G. (2012). E-Book the Matter of Interactive Even Semester Chemical Class XI High School. Unesa Journal of Chemical Education, 1(1), 130135.

Rochmad. (2012). Desain Model Pembelajaran Perangkat Matematika. Jurnal Kreano, 3(1), 59-72.

Rusman. (2010). Model-Model Pembelajaran Mengembangkan Pofesionalisme Guru Edisi Kedua. Jakarta: Rajawali Press.

Rusman. (2012). Model-Model Pembelajaran Profesionalisme Guru. Jakarta : Grafindo Persada.

Sabtaji, A. (2020). Statistik Kejadian Gempa Bumi Tektonik Tiap Provinsi di Wilayah 
Indonesia Selama 11 Tahun Pengamatan (2009-2019). Buletin Meteorologi, Klimatologi, dan Geofisika, 1(7), 31-46.

Santoso, H. B., \& Subagyo. (2017). Peningkatan Aktivitas dan Hasil Belajar dengan Metode Problem Basic Learning (PBL) pada Mata Pelajaran Tune Up Motir Bensin Siswa Kelas XI di SMK Insan Cendekia Turi Slamen Tahun Ajaran 2015/2016. Jurnal Taman Vokasi, 5(1), 40-45.

Sugiyono. (2012). Metode Penelitian Kuantitatif, Kualitatif, dan $R \& D$. Bandung : Alfabeta.

Suparno, P. (2007). Metodologi Pembelajaran

Fisika. Yogyakarta : Universitas Sanata Dharma.
Undang-Undang Republik Indonesia Nomor 20 Tahuan 2003 tentang Sistem Pendidikan Nasional.

Undang-Undang Republik Indonesia Nomor 24 Tahun 2007 tentang Penanggulangan Bencana.

Wahjudi, E. (2015). Penerapan Discovery Learning dalam Pembelajaran IPA sebagai Upaya untuk Meningkatkan Hasil Belajar Siswa Kelas IX-1 di SMP Negeri 1 Kalianget. Jurnal Lensa, 5(1), 1-16.

Wahyuni, I., \& Sudarma, T. F. (2018). Design of Learning Media Physics based on Website. Journal of Physics, 1120012097 : 1-15. 